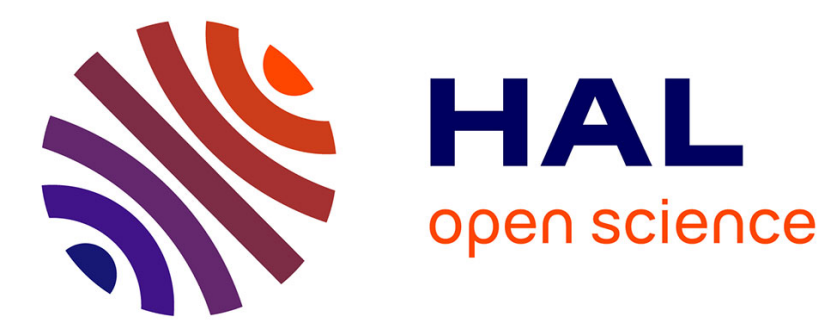

\title{
Tracks, intersections and dead ends
}

Birte Siim, Hege Skjeie

\section{To cite this version:}

Birte Siim, Hege Skjeie. Tracks, intersections and dead ends. Ethnicities, 2008, 8 (3), pp.322-344. 10.1177/1468796808092446 . hal-00571907

\section{HAL Id: hal-00571907 https://hal.science/hal-00571907}

Submitted on 1 Mar 2011

HAL is a multi-disciplinary open access archive for the deposit and dissemination of scientific research documents, whether they are published or not. The documents may come from teaching and research institutions in France or abroad, or from public or private research centers.
L'archive ouverte pluridisciplinaire HAL, est destinée au dépôt et à la diffusion de documents scientifiques de niveau recherche, publiés ou non, émanant des établissements d'enseignement et de recherche français ou étrangers, des laboratoires publics ou privés. 
Copyright $\odot$ SAGE Publications 2008 (Los Angeles, London, New Delhi and Signapore) 1468-7968

Vol 8(3): 322-344;092446

DOI:10.1177/1468796808092446

http://etn.sagepub.com

\title{
Tracks, intersections and dead ends
}

Multicultural challenges to state feminism in Denmark and
Norway

\section{BIRTE SIIM}

Aalborg University, Denmark

\section{HEGE SKJEIE}

University of Oslo, Norway

\begin{abstract}
This article discusses multicultural challenges to state feminism in Denmark and Norway, focusing both on similarities and differences in the two countries policy responses. In spite of important differences, we point towards similar problems and dilemmas in the public responses to multiculturalism and diversity among women connected to a state feminist agenda that in both countries has been rather one-sided in its conception of what women-friendliness may imply. The first part of the paper expands on institutional 'tracks': (Variations in) state feminist traditions, in religious traditions, and in the inclusion of organizations of civil society in political power. The second part explores the framing of the hijab as a political issue of 'intersections' of gender equality versus religious belongings. The third part investigates what we see as a 'dead end' in policy making to prevent violations of women's rights; that is the general, age based, restrictions on family unification as a means to combat forced marriages. Finally, we emphasise the importance of participatory women-friendly politics that include all who are affected by political decisions.
\end{abstract}

KEYWORDS forced and arranged marriages $\bullet$ gender equality $\bullet$ immigration $\bullet$ integration $\bullet$ multiculturalism $\bullet$ religious dress $\bullet$ state feminism

\section{INTRODUCTION}

In policy discourses across Europe, the 'crisis of multiculturalism' is increasingly tied to gender equality concerns, which have come to the forefront of 
European political debates on immigration and integration in recent years. A delimited, explicitly minority group related, gender equality agenda is developing, which aims to counter violations of women's individual rights. Policies adopted within a 'crisis' frame encompass a series of new state initiatives to combat honour based violence, genital mutilation, forced marriages, 'limping' divorces. But a 'crisis' frame may even include measures which actually limit, rather than enhance, individual rights, as when restrictions on the use of religious dress in public settings are portrayed as necessary to counter, in particular, gender hierarchies within Islam.

Crisis awareness is generally raised in combinations of lobbying and dramatic media coverage of individual stories of suffering, which in turn place demands on the political system to act more systematically to prevent violations of women's rights. It is, however, remarkable how these new policies, in both Norway and Denmark, are set apart from traditionally broad gender equality agendas, and largely remains contained within a 'crisis' frame. Comparably little public attention has, in both countries, been paid to traditionally important democratic issues of political participation and representation. Such issues are not totally absent from public agendas. But there seems to be a hierarchical ordering of the new gender equality agenda which then runs counter to what is otherwise claimed to be a strong state feminist tradition in both countries.

This tradition highlights the similarities of the two national gender equality regimes, which are founded on high levels of education and labour market participation, extensive public child care, relatively generous maternity/paternity policies, a comparatively strong gender equality legislation, plus high levels of political participation and inclusion into state political institutions, in some cases supported by institutional regulations of gender balance. In the original formulation, such traits were conceptualized as expressions of a state potential to develop 'women-friendly' societies (Hernes, 1987). In international feminist scholarship, references to 'state feminism' have now mainly come to refer to a form of institutionalized bureaucracy in charge of creating and implementing gender equality policies (Outshoorn and Kantola, 2007). However, the original formulations rather depict an inclusion dynamic, where mobilization 'from below' - i.e. through social and feminist movements, combines with 'integration politics from above' - i.e. party political elites and institutions, to create state initiatives where rights' expansion and institutional presence are two sides of the same coin. In this sense, state feminism mainly refers to the forms of participation which shape gender equality policies, and - in its first, visionary, formulation - the possible development towards a truly women-friendly society.

More recently, the concept of state feminism has been heavily criticized both for its reliance on a particular, social democratic inspired, idealized 'participatory corporatism' (Holst, 2002), and also, for cultivating a kind of 
unified Nordic exceptionalism, which is largely blind to diversities within its own state orders and thus homogenizes conceptions of women's interests (Borchorst and Siim, 2002). Here we address this critique mainly from 'within' the participatory dimension of state feminism. We do not wish to idealize 'participatory state feminism' per se. But we think that an obvious political challenge is today posed by the relative absence of people from ethnic minority backgrounds in the decision making structures of the state, on the national levels where gender equality policies are formalized (Skjeie and Teigen, 2007). This largely holds true whether we refer to the "numerical' or to the 'corporate' channel of power and influence in society (c.f. Rokkan, 1989 [1967]). Important differences can also be observed within the political systems in the two countries under consideration here. But it still seems clear that there is no comparable strong dynamic operating to include minority based locations, voices and points of views in national decision making bodies. This way, there is clearly limited space for diverse conceptions of fair and adequate policy formation within the current frame work of policy making.

In our opinion, this shortcoming has left the field more open to interventions which regard the formation of a delimited, minority group specific, gender equality agenda as the main responsibility of the majority. It opens scope for radical dichotomized versions of the liberal gender equality values as opposed to the patriarchal traditions of 'immigrant culture', and then mainly, as an argument for new restrictions on immigration (for instance Storhaug, 2006). As in other European countries, the radical right parties in Norway and Denmark have also contributed to build, and then capitalized on, this new selective gender equality agenda, while paying little attention to the more traditional ones (c.f. Roggeband and Verloo, 2007; Akkerman and Hagelund, 2007). ${ }^{1}$

However, we can also observe important differences in the content of substantive policy-making in the two countries under consideration here. In this article, we highlight differences in legal regulations and policy discourse on two of the issues that loom large on the new, delimited, gender equality agenda: policies against forced marriages, and policies on religious dress. Danish policies on forced marriages are marked by the controversial '24 year' rule on family unification. In Norway, similar plans for a ' 21 year' rule have recently been abandoned. Similarly, while there are no general restrictions, or blanket bans, on the use of religious dress in public settings in either Denmark or Norway, a recent Supreme Court decision in Denmark rules that employers still, under certain conditions, are allowed to ban hijabs in the work place. In Norway, the Gender Equality Ombud has, on the other hand, found hijab bans in violation of the general prohibition against indirect gender discrimination.

In this paper, we argue that such developments reflect important differences not only in the general political climate, or in the relative importance 
of radical right parties on governmental policies in the two countries, but also differences in actual state feminist traditions and somewhat divergent patterns of 'participatory corporatism'. Not least important is the concurrent tradition of official religious pluralist policies which to a larger extent in Norway aims to include also ethno-religious organizations (cf. Modood, 2000) in corporate structures of dialogue about policy making.

We further claim that there are similar problems and dilemmas in the public responses to multiculturalism and diversity among women connected to a state feminist agenda that in both countries has been rather one-sided in its conceptions of what women-friendliness may imply.

The article is divided into three parts. The first part expands on what we see as institutional 'tracks': (Variations in) state feminist traditions, in religious pluralist policies, and in the inclusion of organisations of civil society in corporatist arrangements. The second part explores the hijab as an issue of 'intersections'; whether, and how, public debate, legal regulations and court decisions frame the religious headscarf in terms of gender equality and religious belongings. The third part investigates what we would deem to be a 'dead end' in policy making to prevent violations of women's rights; that is the general, age based, restrictions on family unification as a means to combat forced marriages. Finally, in the conclusion, we emphasize the importance of public measures aimed at equalizing participation, representation and influence in both of the 'standard' channels that provide access to national political decision making institutions: the numerical as well as the corporate.

\section{INSTITUTIONAL TRACKS}

Economic independence on the one hand, and equal political presence on the other, are twin aspects of the traditional gender equality agenda in both Norway and Denmark. To a large degree, gender equality policies have also been based on a shared family model of 'dual breadwinners', and have developed within a similar welfare state context marked by pervasive cooperation and policy diffusion processes (Borchorst and Dahlerup, 2003; c.f. Langvasbråten, 2008). But while Norwegian gender equality policies also show a strong preference towards formalized gender balance regulations as means to redistribute power and influence, Danish gender equality policies contain no similarly strong institutionalization of gender balance politics. In Norway, the majority of parties have adopted statutes that specify 40-60 min.-max. regulations for party political offices and nominations. Laws regulate the composition of public - both state and municipal - boards and commissions, and most recently, similar min. max. legal regulations have been adopted with regard to the composition of the 
boards of all major public and privately owned companies. In Denmark, the parties to the left formerly practised a system of gender balance politics, which was abolished in the 1990s. There is no similar tradition for gender balance regulations across the party spectrum, and only very weak rules to promote equal participation on public boards and commissions. The inclusion of women in party political elites has therefore taken place mainly without formal regulations. And the relative strong presence within parliamentary politics has not been followed by an equally strong presence in corporate bodies. In this respect, there have been clear limits to diffusion, both within and across countries.

While 'integration' remains the central formal goal of minority oriented policies in both countries, the definition of the term has changed significantly in recent years. Originally launched as an alternative to 'assimilation', it implied a double set of expectations - integration would allow people to preserve cultural identities and traditions, while enjoying the same possibilities, rights and duties to participate in society, that is in 'education, work and organisations' (Djuve and Fridberg, 2004, cited in Langvasbråten, 2008). The shift in Norwegian integration rhetoric and practices has been from a predominantly group oriented focus in the 1970s to a stronger emphasis on individual duties to participate in society and conform to state bound norms and values (Brochmann, 2002). In terms of political participation, the emphasis is clearly more on 'duties' than on 'opportunities'. There is little, if any, diffusion from formalized gender balance politics to equally formalized minority sensitive political recruitment practices. It is remarkable how little political attention there has been with regard to a development of participatory structures which might counter the near total absence of people from ethnic minorities in, for instance, national parliamentary politics. While elective rights in local, municipal, elections are granted in both Norway and Denmark also on a formal non-citizenship basis, and representation issues rank higher on (some) local agendas, central measures to promote political integration have otherwise mainly been contained within policies which encourage minority based cultural and interest group organising (Skjeie and Teigen, 2007).

In Denmark, where policy developments have been described as moving from liberal pluralism to communitarian assimilationism (Hedetoft, 2004; Mouritzen, 2006), ideas about 'national' values and norms clearly constitute a more prominent part of the political debate, where much emphasis is placed on duties to conform to what is explicitly framed as 'Danish' values. Norwegian authorities also tend, if mainly implicitly, to distinguish more clearly between 'cultural' and religious pluralism, and to treat claims based on the platform of religious pluralism as non-controversial also when they involve group rights.

The official Danish integration policies have since the victory of the Liberal-Conservative Government in November 2001 been dependant on 
the Right wing anti-migration party, the Danish People's Party, for parliamentary support. As a result, the restrictive approach to immigration is increasingly combined with punitive integration policies. This has had dramatic effects on the regulation of family unification. Governments have turned to immigration laws and used the issue of forced marriages to legitimize a stricter immigration control in relation to family members symbolized in the infamous '24-year rule' (Grøndahl, 2003). Therefore, the Danish political debate about immigration has, since the 1990s, been described as tending to polarize citizens in ideological groups: more cosmopolitan orientations focus on global concerns, multicultural issues and recognition politics on the one hand, and a more nationalistic orientation which focuses on the so-called 'clash of civilizations', anti-immigration and social cohesion (Thomsen, 2006).

A comparative study focusing on parliamentary debates that specifically address the government's gender equality policies, also shows how these consistently provide a setting where politicians express concern about the conflict between minority cultural traditions and 'Danish' equality norms (Langvasbråten, 2008). To give but one example, from the gender equality action plan of 2003: 'Women and men settling in Denmark are to realize that gender equality is an essential part of Danish society and a core value' (cited in Langvasbråten, 2008). Similarly, Annette Borchorst (2004) has described political debates on gender equality as mainly informed by a claim of Danish citizens having now realized the fully gender-equal society. As of today, in Danish political rhetoric dominated by the liberal-conservative government, the 'equality project' is mainly claimed to be of relevance to 'Muslim countries', or to immigrant minority groups now living in Denmark (Andreassen, 2005, for a parallel description of rhetorical shifts in Dutch politics; see also Roggeband and Verloo, 2007).

Arguably, a parallel 'national values' discourse has been contained more at the fringes of Norwegian political debate. This claim is complicated by the fact that references to national values loom large in the political rhetoric of the radical right Progress Party, which also is one of the largest Norwegian political parties. This party has however, so far, been kept outside any government coalition. Instead, Norwegian authorities, under mainly Christian democratic - conservative coalitions in office from roughly the mid 1990s to the mid 2000s - have concentrated their attention on 'crisis prevention' efforts - producing a series of so called 'governmental action plans' which either aim to prevent forced marriages or violent practices of female genital mutilation. Such problems have not, however, been addressed within a broader scope of state initiatives to combat 'violence in close relationships', which also has been a prominent issue on the public agenda in recent years (c.f. Bredal, 2005). In the Norwegian context, policies are thus rather marked by segmentation into, on the one hand 'minority group', on the other hand, 'majority' concerns. Not surprisingly then, 
minority women's organizations have observed that their influence on public policies is often informally based, and furthermore, mainly limited to such 'crisis' issues (Predelli, 2003).

In Norway, four different types of public funding are available to organizations; subsidies to 'certified' national minority-political organizations - of which three of a total of nine have an explicit gender focus, subsidies to local immigrant organizations, funding for local voluntary based projects, and finally, the system of public funding per memberships for all registered communities of faith. Religious based organising has increased dramatically during the last decade, and religion now forms the single most important basis for immigrant organizing in Norway. Mainly, these are Islamic religious communities, and many are members of the umbrella organization of the Islamic Council in Norway. Increasingly, the Islamic Council also acts as 'liaison' in new forms of corporatist inspired contacts with public authorities, under the umbrella heading of 'religious dialogue'. Otherwise, a clearer cut corporatist, government appointed, commission has the stated purpose to act as an official link between the authorities and the immigrant population (this is also actually the commission's name: $\mathrm{KIM}^{2}-$ The contact commission between authorities and immigrants).

In Denmark, the main political attempt to increase the participation of immigrants in public administration and local politics have been through the Integration Councils that were set up following the first Integration Law in 1998. Their effects have, however, been ambiguous. The democratic aspects were limited because they were only consultative, and since the municipalities could decide the composition of the Integration Councils, their influence was dependent on the local context (Togeby, 2003). Today, the decision to establish an Integration Council or not is left to the municipalities. Otherwise, the main initiatives to promote participation among immigrant groups are through public support for voluntary associations in civil society. Comparative Nordic research notes that the Norwegian model is more clear cut corporatist, as it also has encouraged the formation of national minority-political organizations, whereas the Danish model has relied more on local ethnonational organizations (Mikkelsen, 2003). Mikkelsen also concludes that the relations between Danish authorities and national immigrant organizations seem to be more based on contradictions and suspicion than the more dialogue-oriented forms in Norway (2003: 289).

Similarly, religious pluralist policies are clearly more pervasive in Norway than in Denmark. Both countries have a constitutionally grounded state church. In Norway, equal treatment obligations are interpreted such that all registered communities of faith receive state support according to memberships. All registered communities of faith can also certify marriages. Religious schools are formally privileged as alternatives to the otherwise dominant system of public schools, and run largely on state subsidy, and 
Norwegian anti-discrimination legislation give wide general exemption rights to communities of faith (for a discussion, see Skjeie, 2007a).

In Denmark, there is no concurrent tradition for state sponsored religious pluralism, and no financial support of minority religions. There is a strong tradition of state support for private schools, called 'free schools', that includes religious schools (Togeby, 2003). But the rationale behind this policy is not tied to a promotion of religious pluralism per se, but rather thought of as a form of 'democratic pluralism' Lise Togeby (2003: 154) concludes that Danish authorities have, only to a very limited degree, shown 'the wish and the will' to incorporate immigrant organizations in decisionmaking. In a recent comparative European study of political integration of Islam, Denmark is actually characterized as the country with the least official interest in developing a dialogue with its Muslim residents (Klausen, 2005).

A clear distinction can thus be drawn between the roles that religion plays in public life in Norway and Denmark - between the active 'religious dialogue' politics sought by Norwegian authorities vis-à-vis religious minorities, and the more dismissive policies of Danish authorities. This also implies that Norwegian authorities tend, if mainly implicitly, to distinguish 'cultural' from religious pluralism, and to treat claims based on the platform of religious pluralism as mainly non-controversial also when they involve claims to autonomy for religious groups.

\section{INTERSECTIONS: DEBATES ABOUT RELIGIOUS DRESS}

There is little doubt that 'hijab' represents one of the most controversial issues concerning accommodation of religious pluralism in Europe today. In these controversies over girls' and women's religious attire, a range of liberal principles are regularly activated: state neutrality, gender equality, religious freedom, multicultural accommodation. Controversies are played out on a number of societal arenas: in schools, work places, public offices in parliaments and in courts. The issue illuminates the tensions and ambiguities in integration policies as well as general trends towards assimilation. It also points towards conflicts and tensions between official discourses and individual self-understandings, and raises questions about the meaning of culture and the role of religion in society.

There is no way we can do justice to this complicated issue here. At the outset, we will simply underscore the mere fact that there are no regulations which on general grounds restrict the wearing of religious dress, or other religious symbols, in public settings in either Denmark or Norway. This places both countries on the liberal pole as far as regulation regimes in Europe are concerned. Still, individual cases of hijab prohibitions, 
particularly in work places, regularly occur. Such cases have been tried before courts and court-like bodies in both countries, as claims of religious and/or gender based discrimination. The outcomes of these cases are, however, different in the two countries. In Denmark, employers have been permitted to ban the hijab. In Norway, employers who have tried this have instead been found to have violated the Gender Equality Act and, more recently, the new act against ethnic and religious discrimination, enacted in 2005.

The issue of restrictions has been on the public agenda for years. But while headscarves remain a kind of fixed item, a permanent site of public controversy in Denmark, the debate in Norway in comparison seems more ad hoc, and generally, more subdued. In both countries, the radical right parties have proposed restrictive regulations in parliament. But a comparison of the framing of headscarf issues in two parliamentary proposals, which occurred within a time span of only two months in 2004, also reveals clear differences with regard to radical right rhetoric on the issue (Hopen Standal, 2007).

In the proposal of the Danish People's Party, aimed to encompass all public employees, and also pupils in elementary $\operatorname{school}^{3}$ (B201, 29.04.2004), the headscarf is presented as 'culturally decided'. On this basis, restrictions are only suggested for head gear which 'fall outside the Christian - Judean cultural sphere' and 'Danish' cultural traditions (B201:2, authors' translation, cf. Hopen Standal, 2007:58). Examples provided by the Danish People's Party include the following group demarcations: 'Turkish women's use of headscarves for traditional reasons', 'Palestinian women's use of headscarves for political reasons', and 'Somali women's use of headscarves for religious reasons'. In the Danish People's Party's proposal, the headscarf is mainly construed as being 'offensive' to the majority population, or, as this sometimes is phrased, 'all citizens in the Danish society' B201:2, authors' translation). A distinction is further drawn between public and private expressions of religious belonging, and religious expressions rhetorically delegated to the private sphere when they breach with the dominant tradition (see Andreassen, 2007: 39-42).

The Norwegian Progressive Party's proposal is more vaguely formulated with regard to the substantive content of actual bans, and is set forth within a more general context of an 'integration package'. The motivation underscores that immigrants 'must accept the basic values which the Norwegian society is founded on'. But the main argument is largely concentrated on portraying forms of double victimization: On the one hand on the 'stigmatization' problematic facing young girls, particularly in school contexts, which is ignored by parents who 'sabotage the integration process', on the other hand, the religious head scarf as a symbol of ideologies of suppression and discrimination. The Progress Party cannot 'tolerate that girls [at] such a young age are systematically indoctrinated to accept that women are subordinate and can be suppressed as adults', and the headscarf works to 
exclude children from the school community when they are dressed in a way that will "stigmatize" them' (dok.8 : 93 (2003-2004). ${ }^{4}$ While these are clearly polarizing statements in their own right, the distinctions drawn between what is portrayed as the legitimate majority cultural tradition and a contrary illegitimate minority cultural tradition still seems to be more strongly emphasized in the Danish People Party's rhetoric than in the Norwegian case. The Progress Party's concerns tend to remain with 'oppressed' women and girls, while the Danish People's Party concerns mainly concentrate on the 'offence' suffered by the majority population.

The explicit nationalistic theme in Danish hijab debates is, more generally, underscored in analyses of media portrayals of the headscarf. According to Rikke Andreassen $(2005 ; 2007)$ the scarf now plays a significant role in drawing medialized distinctions between 'us' and 'them' when, for instance, women from ethnic minority backgrounds are often 'illustrated' as wearing the scarf, even though most women don't. 'The ethnic minority woman', wearing a headscarf, plays an important role for the construction of the 'ethnic Danish woman's' identity as already-equal-and-notoppressed. In such media portrayals, the scarf becomes a symbol that organizes, constructs and negotiates gender equality, nationality and identity.

Recently, the hijab has also - in extremely provocative ways - been tied directly to issues of political representation in Demark. In April 2007, the Leftist Party, Enhedslisten, nominated Asmaa Abdol-Hamid, who wears the hijab, as a candidate to run for a seat in Parliament. A member of parliament for the Danish People's Party protested her candidacy based on a comparison of Islam with Nazism and the headscarf with the Nazi Swastika. While most politicians opposed the statement as such, the incident led to a political debate where several political leaders mainly used the occasion to express personal discomforts vis-à-vis veiling in public places, while comparably few saw an opportunity to underscore the importance of equal participation rights (Siim, 2007b). No similar constructions of the hijab have taken hold across the border, in visible public debate. Here, the occasionally fierce debates over the headscarf are largely contained within a distinct form of gender equality frame; that is, as contestations over 'personal autonomy' (Gullikstad, 2007). Proponents of headscarf bans largely claim that bans will contribute to secure personal autonomy and liberate women, while opponents correspondingly claim that bans violate women's autonomy when they disregard agency and independent choice. A competing frame has mainly been presented by minority organizations when claiming that bans foremostly reveal discriminatory attitudes and practices in society. Such efforts might well be strengthened by the more general political approach to religious pluralism in Norway. Generally, Norwegian public authorities have pursued an active policy of accommodation of religious dress, and mainly regarded this as a question of non discrimination between religions. For instance, with respect to the wearing of religious attire in schools, the 
very existence of a Christian intention clause for educational institutions makes it unacceptable to deny the expression of other religious beliefs, public authorities regularly explain. Accommodating hijab thus falls into a category of policies promoting religious pluralism, without further efforts to elaborate on possible deeper symbolic meanings of the scarf. All in all, it seems fair to claim that there has been modest public debate over potential religious in-group submission regimes in this respect, and that highly critical voices are comparably few.

When human right activists and scholars debate the issue, it is mainly framed in terms of religious choice (see for instance Høstmælingen, 2004). Building on the 'discrimination' frame, minority based women's organizations have also sought to establish a tie between the right to wear the hijab and the right to gender equality. Here, the distinct form of gender equality frame refers to (equal) economic independence through labour market participation. The first hijab case brought before the Norwegian Gender Equality Ombud, in 2004, was actually a compilation of 14 different cases of work place bans gathered by two minority women's organizations - the Mira Centre and the Islamic women's group in Norway - in cooperation with the national, government sponsored, Centre to combat ethnic discrimination (SMED, Senter mot etnist diskriminering). These were all presented as cases of gender discrimination under the prohibitions in the Gender Equality Act, which at the time was the only comprehensive anti-discrimination law in place in Norway. ${ }^{5}$ The complaint resulted in a clear decision by the Ombud that prohibitions of hijab in work places were in violation of the ban on indirect gender discrimination (see Mile, 2004: 222). One case was brought before the Appeals Board, which holds the decision power in matters of continued dispute. A large hotel in the Oslo area had practised an employee uniform code which the hotel management claimed was not reconcilable with the use of head coverings. The appeals board agreed with the Ombud in her evaluation that this prohibition mainly would have negative consequences for women employees using hijab. The uniform code - although gender neutral in wording - could thus be seen to produce gender-specific discriminatory effects. In determining this, the Ombud also compared such restrictions to the contrary, accommodating, uniform regulations within the military services (i.e. turbans). She reasoned that many Muslim women wear the hijab because of religious reasons and that it is thus a part of their personal integrity and that situations may well occur where they could not accept to work if they could not use the headscarf. A prohibition would thus entail significant disadvantages for these women (cf. Craig, 2006). In two more recent decisions, the Ombud has upheld this general line of reasoning. In the latest one, a hijab ban was tried both according to the Gender Equality Act and the new act against ethnic and religious discrimination (2005), and the ban found in violation on both prohibition grounds. 
This series of judgements by the Norwegian Ombud are important not least because they specifically address hijab as an issue of individual gender equality rights in ways which challenge the 'crisis' frame, and which also contribute to 'normalizing' the whole headscarf issue. The Ombud explicitly refrains from considerations about subjugate symbolic meanings of the scarf, and instead treats the complex as an intersecting individual right. In this, the decisions also run counter to the generals statements made by, for instance, the European Court of Human Rights, in the Dahlab and Sahin headscarf cases, where the court takes special pains to repeat respectively the Swiss and Turkish states' notions that the wearing of a headscarf 'seems hard to reconcile with the principle of gender equality' (cf. Skjeie, 2007b)

In Denmark, there is no similar Ombud institution in charge of supervising anti-discrimination legislation. Individual complaints, mainly about religious discrimination, have here been handled by the regular court system. The courts have disagreed in rulings on different cases, but recently, the Supreme Court has upheld a right for employers to adopt uniform codes which prevent the use of the hijab. We will briefly outline two of the Danish cases, where conclusions are contradictory in terms of employers' right to ban religious dress at work. The first case was raised in 1998 by a young Muslim girl who wanted to do an internship in a big department store as part of her school education. The employer sent her home, because she would not take off her headscarf which she stated she wore for religious reasons. The court found the ban on headscarves to be an indirect discrimination towards a specific religious group (Hansen, 2003; 243). The sentence led several large chain stores to change their previous practice of not hiring veiled women. But then the seminal Føtex case came, in 2003. Najla Ainouz had been employed in a department store chain Føtex for five years when she decided to wear a headscarf. The employer argued that she did not live up to the general dress code of the supermarket, which demanded that employees had to be 'professionally and nicely dressed'. Her trade union argued that she was the victim of indirect discrimination. In 2003 the court acquitted Føtex and ruled that the dismissal was legal due to the the supermarket's general uniform code. The sentence was appealed and the case was taken to the Supreme Court, which confirmed the decision in January 2005. The final court decision was a surprise to human rights lawyers. The previous court case had ruled in favour of indirect discrimination in relation to the Law Against Discriminatory Behaviour on the Labour market (from 1996), whereas the rulings in the Føtex case mainly upheld the right of the employers to decide the dress code (Andreassen, 2007).

The Norwegian Ombud's reasoning on headscarves as intersecting gender equality rights is unambiguously in line with both the reasoning and collective actions of minority women's organizations and government sponsored agencies on the issue. It could, actually, be seen as an exemplary case of minority driven and - sensitive state feminism in action. The Danish 
courts' reasonings represent a more traditional judicial 'balancing act' of individual religious rights on the one hand, and employers' rights on the other. Comparatively speaking, the right to wear the hijab is thus clearly better protected in Norwegian than in Danish judicial practice.

It is indeed remarkable how differently the popular, political and legal discourses are played out in the two countries. The headscarf issue is clearly more controversial in Denmark, where it is regularly framed as being juxtaposed to 'Danish' majority culture, values, and traditions. In Norway, the hijab issue is more regularly treated both as an integral part of official religious pluralist policies and an issue of intersecting religious and gender equality rights. General public sentiment is not in favour of liberal policies, as a series of public opinion polls reveal. But in policy formation processes on the hijab it seems that minority based interests have contributed more strongly to shape the discourse. In this respect, it is probably also important that no divisive public conflict has appeared between feminist voices and voices from the mosque.

\section{DEAD ENDS: GENDER AND IMMIGRATION}

In both Denmark and Norway, the serious challenge of how to combat forced marriages has been equally prominent on public agendas for more than a decade. To force someone into marriage is a clear human rights violation, which states have a similarly clear obligation to try to prevent. Young people who risk being forced into marriage against their will also have special protection needs: many have changed their names and live in secret addresses to avoid being forced to marry or face sanctions after having run away from home to escape.

Anja Bredal (2005) has, in great detail, outlined important similarities, as well as differences, in Nordic policy approaches to combat forced marriages. Important to a comparison of respectively Norwegian and Danish policies, is the particular strong focus in Denmark on seeing marriage as a strategy for immigration. Policy development is marked by a generalization from individual cases of forced marriage to the marriage practices of whole minority groups, where distinctions between arranged and forced marriages are blurred, and both practices tend to be regarded as equally unacceptable.

In both countries, there is a general development towards a tightening of border controls, and new restrictions on family unification, as a means to combat forced marriages. This in turn implies a strengthened focus on how international human rights obligations actually are balanced in national legislation on immigration. But in Denmark, as Bredal (2005) notes, the dominant policy strategy to combat forced marriage was from the start 
concentrated on efforts to restrict the right to family unification with a spouse from abroad. Over the years, this has been linked to a more general development toward what is now referred to as one, if not the, strictest immigration policy in Europe (Grøndahl, 2003). In 2000 the coalition parties of Social Democrats and Liberal Centre adopted special rules to prevent forced marriages between young Danish and foreign citizens (Grøndahl 2003: 188-189). ${ }^{6}$ The present Liberal Conservative government dramatically tightened the right to family reunification in 2002 by adopting a mandatory age of 24 for couples wanting to marry a foreign citizen and by extending the obligation to economic self-sufficiency. The law also provided that couples had to prove that their connection to Denmark was stronger than their connection to any other country ['tilknytningskravet'] in order to be allowed to unite in Denmark. ${ }^{7}$ The opposition has generally supported this change, provided it was not in conflict with Denmark's obligations according to international conventions. It is contested whether Danish immigration legislation actually lives up to the relevant conventions. The legislation has been criticized by the Danish Institute for Human Rights (2004) for the violation of the right to family life $^{8}$ (the European Convention of Human Rights, article 8), by the CEDAW committee in 2002, and more recently by the Report of the Council of Europe's Commissioner on Human Rights. This report was followed by a political debate between the government and the opposition in the summer of 2004, where the opposition demanded that the administration of the Integration law should be according to the rules of ECHR (Siim, 2007a).

In Norway, the policy discourse has traditionally been marked by applying a more consistent distinction between arranged marriages and use of force. The first of a series of governmental action plans on forced marriages, published in 1998, discussed at length such distinctions. ${ }^{9}$ Important was also the plan's stress on the need to engage in dialogue with relevant minority groups, as well as securing assistance to those who fear or have been victims of forced marriage. The plan can largely be described as a 'civil society' oriented effort; as it prioritized support for organisations working with young people in crisis situations; the Women's shelter movement and the Red Cross among others. As Bredal observes, the most striking aspect of this plan was possibly its remarkably short section on legal regulations. No mention was made of using stricter immigration laws to fight forced transnational marriages. Rather, the only law-based action appeared, according to Bredal (2005), to suggest a liberal immigration practice, as the Action Plan stated that the authorities will 'investigate the possibilities for continued residence in Norway after the marriage annulment'.

However, when the Norwegian government in 2002 issued a 'Renewed Initiative against Forced Marriage', ${ }^{10}$ ten of a total of 30 new measures were now law-related punitive actions. The Marriage Act already held a special provision for the annulment of forced marriages, and allows either of the 
spouses to bring civil action against the other in order to have their marriage annulled, if he or she has been forced into the marriage. Forced marriage has also been illegal according to the general provisions of the General Civil Penal Code on illegal use of force. This provision was now amended to include a specific subsection on forced marriage. According to this provision, both the spouse and/or the family members involved in organizing the forced marriage can be charged, and risk imprisonment for up to six years, and a mandatory prosecution clause was introduced in cases of forced marriage so that the perpetrators may be prosecuted without the victim's consent. This mirrored the mandatory public prosecution provision regarding domestic violence cases, instituted in 1988. Notably however, the package of new state initiatives to combat forced marriages was kept strictly apart from the activities of the group which, by government appointment, and at roughly the same time, prepared a report on violence against women. This latter report documented the situation of women exposed to violence from a present or former partner, and made recommendations on policies and measures aimed both at improving the situation of victims and preventing violence against women (NOU, 2003:31).

Contrary to the Norwegian governmental plans, the Danish Government's Action Plan for 2003-200511 addresses both 'Forced, Quasi-forced and Arranged Marriages'. The initiative states that the overall objective of political interventions is not only to prevent marriages that involve force, which is against the law, but also to prevent all forms of arranged marriages, including marriage between cousins. The document stresses that forced and arranged marriages have the same negative effects in relation to selfdetermination, cultural conflicts, and lack of integration. References to both the Norwegian and British Action Plans against Forced Marriages, to the Human Rights Convention of 1948 and the Danish law against forced marriage, helped to blur differences between forced and arranged marriages. The document thus identifies the main problem as a value conflict and a clash of culture between the Danish majority norms of gender equality and the cultural tradition of forced and arranged marriages that lead to oppression and lack of self-determination for minority women (Siim, 2007a).

In Norway as well, references to the state's obligation to prevent forced marriages have more recently given rise to proposals about stricter immigration regulations for family reunification. The public commission, which drafted a new Aliens Act in 2004, also launched a proposal about a 21 year age limit for family reunification, partly modelled on the Danish '24 year' rule. Since then, controversy has raged. In the autumn of 2006, the new left coalition government issued a public hearing of 'additional demands' to a possible 21 year limit, which specified a series of measures aimed at preventing situations where young people were forced to leave the country to marry, and forcefully held in this country until the age of 21 . However, this 
public hearing mainly demonstrated the extent of opposition among organizations in civil society against the intertwining of policies against forced marriages and a stricter immigration regime (Skjeie and Teigen, 2007). As a number of organizations pointed out, a '21 year rule' could not distinguish between forced and other marriages, and was thus quite meaningless as a targeted effort to combat the first. Such regulations would mainly contribute to a stigmatization of immigrant groups. Some organizations also maintained that it represented an unacceptable threat towards the right to family life. Minority-political organizations were furious, and supported in their protests by most of the large humanitarian organizations and the anti-discrimination and human rights institutes. Actually, on the basis of this hearing the government backed down. It risked compromising the whole institute of public hearings - which otherwise is so central to the 'participatory corporatism' of Norwegian social democratic traditions. The restriction attempt had been pushed by the social democratic party - one of three coalition partners - and it clearly helped the organizations' cause that the two other parties within the government were hesitant on this issue.

In the Norwegian context, it also seems fair to argue that the original distinction between forced and arranged marriages has contributed to prevent issues of women's rights from turning into issues of border control. Here only one minority-political organization stands out as instrumental in the maintenance of this focus on abuse of women within minority groups as an immigration problem. This is the private foundation Human Rights Service (HRS), which calls itself a think-tank on integration issues with a particular focus on 'the rights of women and children - and on such violations of those rights as forced marriage, female genital mutilation, and honour killings' (cited in Bredal, 2005). ${ }^{12}$ HRS has consistently sought to influence state policies to combat practices of forced marriage, and campaigned for the tightening of immigration controls as a major strategy. Their proposals have in particular been taken up and presented in Parliament by the Progress Party, which has also been instrumental in securing funds directly from the state budget to HRS. Interestingly, the organization has also served as advisor to the Danish minister in charge of immigration and integration policies (information provided by Bredal, 2005). It has in this respect been clearly more successful in Denmark.

The Danish debate about forced and arranged marriages cannot solely be interpreted as expressions of a 'clashes of cultures' theme where 'patriarchal' and 'modern' family forms collide. But it seems to build on clearly stated conflicts between an individualistic family tradition and practice and the more collective family orientations of many migrant groups. There is no doubt that the restrictive immigration/integration legislation has created a strong pressure towards cultural assimilation that has contributed to exacerbate conflicts between minority and majority groups about cultural values connected with family forms and gender roles. From this perspective, the 
linkage of national values to a gender equality model based upon a dual breadwinner and highly individualist family model has contributed to make the issue of forced and arranged marriages an arena for acute politicalcultural conflicts between the majority and minority (Siim, 2007a).

In Norway, a recent investigation of participation structures in two public hearings of new policy initiatives to combat forced marriages shows that public authorities clearly strive to include in particular the most visible, although very few, national minority women's organizations. They do not however, to the same extent, make efforts to include organizations within the women's movement per se. Nor, for that matter, do these organizations demand to be included. This way, participation in public hearings reinforces current divides between 'minority' and 'majority' gender equality policies (Skjeie and Teigen, 2007).

\section{CONCLUSION: STATE FEMINISM REVISITED}

'State feminism' highlights the similarities of Scandinavian gender equality regimes in relation to women's labour market participation, access to public childcare and political participation and representation. As outlined in the introduction, state feminism's original formulations depict an inclusion dynamic where mobilization 'from below' combines with 'integration politics from above' to create state policies where rights' expansion and institutional presence are two sides of the same coin. In multicultural terms, state feminism has by no means fulfilled its promises. Rather, the gap seems wide between the will to promote institutional political presence and the will to initiate public policies. Majority based viewpoints combine with exclusive whiteness in core political institutions. Here a new public agenda is fast developing, but with limited scope and an inherent tendency to divide 'gender equality' into respectively 'minority group' and 'majority' concerns.

The minority group agenda is clearly influenced by the radical right's recent appropriation of gender equality concerns. We agree with Akkerman and Hagelunds' (2007) observation that the discourse on gender has helped to legitimate a shift away from multiculturalism among left parties, while providing a potentially respectable anti-immigration position for radical right parties. Within the confines of the 'crisis' frame, the radical right can defend liberal values of individualism, human rights and gender equality in blatantly monoculturalist terms. This frame is not challenged in any systematic way either by left parties or by the feminist movements, which often, in both Norway and Denmark, are marked by divisions and lack of institutional bridges between traditionally majority based organizations and new minority based organizations. From this, it seems clear that 
multiculturalism poses specific problems for Nordic state feminism when it comes to recognizing cultural diversity in general, and to accepting different models of gender equality and the family in particular. Obviously, the dilemma between multiculturalism and the rights of immigrant groups on the one hand, and state feminism and the rights of woman on the other hand, are a contextual conflict. However, a kind of 'sobering moment' in times of such conflict is also offered when we consider the treatment of the religious headscarf in Norwegian judicial, state, and minority based political practice.

But the very formula of 'state feminism' will anyhow collapse if and when the dynamic is unbalanced - i.e. when the participatory dimension, and 'mobilization from below', yields to the policy making dimension and 'integration from above'. As an inclusion dynamic, state feminism is today challenged from two sides - from the fragmentation of the feminist movement, as well as from the general, relative, political marginalization of immigrant groups. In both Norway and Denmark it is possible to identify what we will call a 'gender equality paradox', which refers to the simultaneous inclusion of women from ethnic majority backgrounds and exclusion of women from ethnic minority backgrounds in core political institutions such as parliament and government. Access to the other 'standard channel' to influence and power, the corporate decision making structure, is also limping. Here, integration 'schemes' concentrate on limited, ad hoc, involvement of organized interests, while paying little attention to individually based access to boards and commissions.

Overall, we regard the limited access for minority backgrounds, interests and viewpoints on the public sites where policies are formalized and sanctioned as a serious political challenge. But this general charge also conceals some important differences with regard to substantive policy formation processes in the two countries under consideration here.

The current lack of broad and integrative gender equality perspectives formulated 'from below' is probably most problematic in the Danish case, which traditionally has relied more on grass roots mobilization. Here, traditional gender equality politics has waned from public agendas, to be replaced by a highly selective minority gender equality politics primarily targeting immigrant communities. In the Norwegian case, a continued political ambition to expand gender balance politics has not been combined with similarly eager efforts to include minority based locations, voices and points of views in core decision making bodies. At the same time, while public authorities may take special pains to include the comparably few national minority women's NGOs in public commissions and/or hearings when 'crisis prevention' schemes are to be developed, no similar efforts are made to include the traditional feminist organizations in these. In this way, a somewhat differently construed divide between 'minority group' and 'majority' concerns is also developing in Norway. 
The divergent 'solutions' on the two policy issues examined in this paper, policies to combat forced marriages, and debates about the hijab, still show how a stronger corporatist tradition in Norway actually has contributed to shape the policy formation options. The combined effort of minority political organizations, social and humanitarian NGOs, and anti-discrimination agencies protesting the introduction of a ' 21 year' rule for family unification, is one example. The framing of hijab in the Norwegian context, as an issue of intersectional religious and gender equality rights, is another. Here both minority organizations and human right agencies have fought hard to claim hijab bans as proof of discriminatory attitudes in society, and received support in this framing through the rulings of the Gender Equality Ombud.

How, then, may public agencies intervene effectively against practices that are harmful to women, without in the process demonizing minority groups? This question looms large also on the agenda of this special issue of Ethnicities on the rights of women and the crisis of multiculturalism. From a normative democratic perspective, we would argue that proactive public strategies must combine with civil society measures, which enable a just recognition of the relevant distinctions between different cultural and religious practices. Pragmatically, we would point to the political-judicial resolution of 'headscarf' conflicts in Norway as a 'best practice' example in this respect. The state has a clear obligation to protect and further individual human rights. Self evidently, this also includes the right to participation and voice. From this double obligation follows a specific challenge for the state: to work hard to facilitate participation; to put much more institutional energy into the inventive development of participatory schemes, so that all who are affected by political decisions are equally included in their making.

\section{Notes}

1 For instance, the Norwegian Progress Party, which is an ardent defender of state intervention to secure women's rights in immigrant family relationships, also thinks that the Gender Equality Act should be abolished and the Ombud institution put to rest, as relationships between men and women should develop naturally and without state intervention. This point is elaborated by Akkerman and Hagelund (2007) in a comparison of Norwegian and Dutch radical right policy and rhetoric.

2 KIM: Kontaktutvalget mellom innvandrerbefolkningen og myndighetene.

3 Folketinget: http://www.folketinget.dk/. Samling: 2003-04-B201 Lovforslag om forbud mod tørklæder: (B201 Forslag til Folketingsbeslutning om forbud mod at bære kulturbestemt hovedbeklædning). URL: http://www.folketinget.dk/ samling/20031/salen/B201_BEHI_98:6_(NB).html. For links to the Dansih debate about the headscarves see the homepage for the VEIL project 'Values, Equity and Differences in Liberal Democracies. Debates about Muslim Women's Headscarves in Europe' (http://veil-project.eu). 
4 Dokument nr. 8: 93 (2003-2004): Privat forslag fra stortingsrepresentantene Carl. I. Hagen, Per Sandberg, Arne Sortevik og Karin S. Woldseth (Private bill proposal from Members of Parliament Carl. I. Hagen, Per Sandberg, Arne Sortevik and Karin S. Woldseth). URL: http://www.stortinget.no/dok8/2003/ dok8-200304-093.html

5 A general prohibition of ethnic and religious discrimination was not put into force in Norway until 2006.

6 One was 'the attachment' rule - that couples must have an attachment to Denmark at least as strong as that to any other country. Another was the obligation for the person living in Denmark to have a 'home of a reasonable size'.

7 This requirement does not apply to family unification if the spouse is a citizen in a European country. EU citizens have the right to move freely within the territory of another member state, when the purpose is to apply for employment, according to article 39 of the Treaty establishing the European Community (EC).

8 Family-unification has become politicized and there is now an EU Directive on Family Unification from Third country nationals (Council Directive 2003/86/ EC). As a result of the Danish adoption of four reservations to the Mastricht Treaty - the EURO, the European army, EU citizenship and legal and interior matters - Denmark is allowed to have stricter rules concerning familyunification than other member-states are allowed to have according to EU Directive 2003/86 on family-unification. The '24 year provision' in the Danish Alien Act $\$ 9$ is therefore a European exception. http://www.europakommissionen. dk/eupolitik/noegleomraader/juridiske_menneskeret/familiesammenfoering/. Direktive om ret til familiesammenføring, 22 September 2003.

9 http://www.regjeringen.no/nb/dep/bld/dok/rapporter_planer/planer/2001/Hand lingsplan-mot-tvangsekteskap.html?id=276888

10 http://www.regjeringen.no/nb/dep/bld/tema/andre/Tvangsekteskap/Forneyetinnsats-mot-tvangsekteskap-varen.html?id=417218

11 Handlingsplan for regeringens indsats I perioden 2003-2005 mod tvangsægteskaber, tvangslignende ægteskaber og arrangerede ægteskaber, 15 August 2003. http://www.lige.dk/Files/PDF/handlingsplan_tvang.pdf

12 HRS has also been a fierce proponent of headscarf bans and a very active participant in attempts to frame the headscarf as an expression of (an intolerable) subjugation of women and girls. See for instance Storhaug, 2007.

\section{References}

Akkerman, T. and A. Hagelund (2007) “"Women and Children First!” Antiimmigration Parties and Gender in Norway and the Netherlands', Patterns of Prejudice 41(2): 197-214.

Andreassen, R. (2005) 'The Mass Media's Construction of Gender, Race, Sexuality and Nationality: An Analysis of the Danish News Media's Communication about Visible Minorities 1971-2004', unpublished PhD dissertation, Department of History, the University of Toronto, Canada.

Andreassen, R. and B. Siim, (2007) ‘Country-report, Denmark. January, 2007', report 
for the VEIL-project, Values, Equality and Diversity in Liberal Democracies, Debates about Muslim Women's Headscarves, Institute for History, International and Social Relations, Aalborg University.

Borchorst, A. (2004) 'Skandinavisk likestillingspolitik tur-retur, på dansk billet' (Scandinavian equality politics, a Danish version], Nytt Norsk Tidsskrift 3-4: 264-74.

Borchorst, A. and B. Siim (2002) 'The Women-friendly Welfare States Revisited', NORA 10(2): 90-8.

Borchorst, A. and D. Dahlerup, eds (2003) Ligestilling som diskurs og praksis (Equality and discourse and practice). Fredriksberg: Samfundslittedratur.

Brochmann, G. (2002) 'Velferdsstat, integrasjon og majoritetens legitimitet' (Welfare state, integration and the legitimacy of the majority), in G. Brochman, T. Borchgrevink and J. Rogstad (eds) Sand i maskineriet, Makt og demokrati i det flerkulturelle Norge, pp. 27-55. Oslo: Gyldendal Akademisk.

Bredal, A. (2005) 'Tackling forced marriages in Norway and Denmark: Between women's rights and immigration control', in L. Welchman and Z. Hossain (eds) 'Honour crimes' Paradigms and Violence Against Women, pp. 482-509. London: Zed Books.

Craig, R (2006) 'The Religious Headscarf (Hijab) and Access to Employment under Norwegian Antidiscrimination Laws', doctoral lecture, University of Oslo, Norway.

Danish Parliament (n.d.) Danish parliament home page [http://www.ft.dk/?/samling 20031/beslutningsforslag_oversigtsformat/B201.htm]

European Commission (n.d.) [http://www.europakommissionen.dk/eupolitik/ noegleomraader/juridiske_menneskeret/familiesammenfoering/]

Grøndahl, M. (2003) 'Familiesammenføring - fra verdensrekord til verdensrekord' (Family unification - from world record to world record), in C. Fenger-Gørn, K. Qureshi and T. Seidenfraden (eds) Når du strammer garnet - et opgфr med mobning af mindretal og ansvarslфs asylpolitik, pp. 184-211. Aarhus: Aarhus Universitetsforlag.

Gullikstad, B. (2007) 'Kan man være likestilt med hijab?' [Can you be equal with hijab?], interview, Kilden, 23 November, 2007 [http://kilden.forskningsradet.no/ c16880/artikkel/vis.html?tid=48863].

Hansen, N.E. (2003) 'Diskrimination på arbejdsmarkedet', (Discrimination in the labour market), in C. Fenger-Grøn, K. Qureshi and T. Seidenfaden (eds) Når $d u$ strammer garnet - et opg $\emptyset$ r med mobning af mindretal og ansvarsl $\phi$ s asylpolitik, pp. 235-53. Aarhus: Aarhus University Press.

Hedetoft, U. (2004) 'Magten, de Etniske Minoriteter og det Moderniserede Assimilationsregime I Danmark' (Power, ethnic minorities and the modernized assimilation regime in Denmark), GRUS 71: 69-92.

Hernes, H. (1987) Welfare state and women power - essays in state feminism. Oslo: Norwegian University Press

Holst, C. (2002) Kjønnsrettferdighet (Gender justice). Oslo: Gyldendal.

Hopen Standal, D. (2007) 'Muslimske kvinner sitt medborgarskap i fleirkulturelle og fleirreligiøse samfunn' (Muslim women's citizenship in multicultural and multireligious societies), unpublished master's thesis, Department of Political Science, University of Oslo, Norway.

Høstmælingen, N. (ed.) (2004) Hijab i Norge - trussel eller menneskerettighet? (Hijab 
in Norway - a threat or a human right?). Oslo: Abstrakt forlag.

Klausen, J. (2005) The Islamic Challenge: Politics and Religion in Western Europe. Oxford: Oxford University Press.

Langvasbråten, T. (2008) 'A Scandinavian Model? - Gender Equality Discourses on Multiculturalism', Social Politics 15(1): 32-52.

Lister, R., F. Williams, A. Antonnen, J. Bussemaker, U. Gerhard, J. Heinen, S. Johansson, A. Leira, B. Siim and C. Tobbio, with A. Gavanas, (2007) Gendering Citizenship in Western Europe. New Challenges for Citizenship Research in a Cross-national Context. Bristol: Policy Press.

Mikkelsen, F. (ed.) (2003) 'Indvandrerorganisationer i Norden' (Immigrant organisations in the Nordic countries), Kbh.: Nordisk Ministerråd, Akademiet for Migrationsstudier i Danmark, Nord 2003: 11.

Mile, K. (2004) 'Diskriminering av kvinner' (Discrimination against women), in N. Høstmælingen (ed.) Hijab i Norge - trussel eller menneskerettighet?, pp. 220-30. Oslo: Abstrakt forlag.

Modood, T. (2000) 'Anti-Essentialism, Multiculturalism, and the "Recognition" of Religious Groups', in W. Kymlicka and W. Norman, (eds) Citizenship in Diverse Societies, pp. 175-95. Oxford: Oxford University Press.

Mouritsen, P. (2006) 'The Particular Universalism of a Nordic Civic Nation: Common Values. State religion and Islam in Danish political culture', in T. Modood, A. Triandafyllidou and R. Zapata-Barrero (eds) Multiculturalism, Muslims and Citizenship, pp. 70-93, Oxford: Routledge.

NOU (2003) The Right to a Life without Violence, p. 31. Oslo: Justis-og politidepartementet.

Outshoorn, J. and J. Kantola, eds (2007) Changing State Feminism. Basingstoke: Palgrave Macmillan.

Predelli, L.N. (2003) Uformelle veier til makt: Om minoritetskvinners politiske innflytelse (Informal paths to power: About the political influence of minority women). Oslo: Makt- og demokratiutredningen, rapport no. 60.

Roggeband, C. and M. Verloo (2007) 'Dutch Women are Liberated, Migrant Women are a Problem: The Evolution of Policy Frames on Gender and Migration in the Netherlands, 1995-2005', Social Policy \& Administration 41(3): 271-88.

Rokkan, S. (1989[1967]) Stat, Nasjon, Klasse [State, Nation, Class]. Oslo: Universitetsforlaget.

Siim, B. (2007a) 'The challenge of Recognizing Diversity from the Perspective of Gender Equality - Dilemmas in Danish citizenship', CRISPP - Critical Review of International Social and Political Philosophy, 10(4): 491-511.

Siim, B. (2007b) 'Globalisering, multikulturalisme og medborgerskab - ligestillingsdilemmaer', (Globalisation, multiculturalism and citizenship - equality dilemmas), Tidsskriftet Politik 10(2): 78-89.

Skjeie, H. (2007a) 'Religious exemptions to equality', CRISPP - Critical Review of International Social and Political Philosophy 10(4): 471-490.

Skjeie, H. (2007b) 'Headscarves in Schools: European Comparisons', in T. Loenen and J. Goldschmidt (eds) Religious Pluralism and Human Rights in Europe: Where to Draw the Line?, pp. 129-45. Amsterdam: Intersentia.

Skjeie, H. and M .Teigen (2003) Menn i mellom. Mannsdominans og likestillingspolitikk (Between men: Male domination and equality politics. Oslo: Gyldendal Akademisk. 
Skjeie, H. and M. Teigen (2007) 'Likestilling og minoritetspolitikk' (Equality and minority politics), Tidsskrift for kjønnsforskning 2: 21-38.

Storhaug, H. (2006) Men størst av alt er friheten - om innvandringens konsekvenser (Freedom is the greatest - about the implications of immigration). Oslo: Kagge forlag.

Storhaug, H. (2007) Tilsørt. Avslørt. Et oppgjør med norsk naivisme (Veiled. Unveiled: A Protest against Norwegian Naivism). Oslo: Kagge forlag.

Togeby, L. (2003) Fra fremmedarbejdere til etniske minoriteter (From guestworkers to ethnic minorities). Aarhus: Aarhus University Press.

Thomsen, Frølund, J.P. (2006) Konflikten om de nye danskere (The conflicts about the new Danes). København, Akademisk Forlag.

BIRTE SIIM is Professor of Gender Studies in the Department for History, International and Social Studies at Aalbog University, Denmark. Address: Institute for History, International and Social Studies, Aalbog University, Fibigerstræde 2, DK-9220 Aalborg East, Denmark. [email: Siim@ihis.aau.dk].

HEGE SKJEIE is Professor of Political Science in the Department of Political Science at the University of Oslo, Norway. Address: Department of Political Science, University of Oslo, PB 1097 Blindern, 0317 Oslo, Norway. [email: hege.skjeie@stv.uio.no] 